\title{
BACK-CALCULATION OF TOTAL LENGTH OF ARGENTINE SEABASS Acanthistius patachonicus USING MORPHOMETRIC RELATIONSHIPS OF BONES AND MEASUREMENTS OF THE BODY
}

\author{
Cecilia M. Riestra ${ }^{1}$, Jorge E. Perez Comesaña ${ }^{2,3, \dagger}{ }^{\dagger}$ Karina A. Arias ${ }^{3}$, \\ LEANDRo L. TAMINI ${ }^{3}$ and Gustavo E. Chiaramonte ${ }^{2,3}$ \\ ${ }^{1}$ Instituto Nacional de Investigación y Desarrollo Pesquero (INIDEP), \\ Paseo Victoria Ocampo No 1, Escollera Norte, B7602HSA - Mar del Plata, Argentina \\ e-mail: cmriestra@inidep.edu.ar \\ ${ }^{2}$ División Ictiología, Museo Argentino de Ciencias Naturales "Bernardino Rivadavia", \\ Av. Ángel Gallardo 470, C1405 - Ciudad Autónoma de Buenos Aires, Argentina \\ ${ }^{3}$ Estación Hidrobiológica de Puerto Quequén, \\ Av. Almirante Brown y Calle 520 s/n, B7631 - Quequén, Argentina
}

\begin{abstract}
Predictive regression equations were generated to estimate total length of the Argentine seabass (Acanthistius patachonicus) using skull and pectoral girdle bones, specific body, and otolith lengths. Regressions of skull and pectoral girdle bones, specific body and otolith lengths were all statistically significant. Generating regressions between specific bones and external characteristics of the body meaningfully increases the ability to analyse the information obtained from studies of stomach contents of predator fish from the Southwestern Atlantic Ocean.
\end{abstract}

Key words: Diagnostic bones, piscivores, top predators, diet.

\section{INTRODUCTION}

Argentine seabass or "mero" Acanthistius patachonicus (Jenyns, 1842) is a benthic-demersal fish that inhabits both soft and hard bottoms at depths not exceeding $100 \mathrm{~m}$. Distribution of this species ranges from $30^{\circ} \mathrm{S}$ (Brazil) to $48^{\circ} \mathrm{S}$ (Patagonia, Argentina) in the Southwestern Atlantic (SWA) (Cousseau and Perrotta 1998). Argentine seabass comprises an important prey for top predators such as the South American sea lion (Otaria flavescens), cooper shark (Car- charhinus brachyurus), tope shark (Galeorhinus galeus) and grey nurse shark (Carcharias taurus) (Koen Alonso et al. 2000; Lucifora 2003; Lucifora et al. 2006).

It is important to determine the role that each species plays within the ecosystem and its position in the trophic network for a better understanding of predator-prey interactions (Pauly et al. 1998b). Interactions between species affect the dynamics of marine fish populations (Alonso et al. 2003), while community structures are strongly influenced by piscivorous predators (Lyons and Magnuson 1987; Tonn et al. 1992; Scharf et al. 1997). On the other hand, studies in trophic 
ecology have become relevant in recent years because of their use in the construction of indices for evaluating the health of ecosystems (Pauly et al. 1998a, 1998b). Regarding these indices, the trophic level has been extensively used to evaluate the state of fisheries, as well as to determine the existence of over-exploitation and the sustainability of these fisheries over time (Pauly et al. 1998a, 2001, 2002). Therefore, it is extremely important to accurately achieve great precision in the evaluation of the diet of any predator, including size and weight of the ingested prey, information that is essential to define future management and conservation strategies (Cherel et al. 2000).

Because of the difficulty of directly assessing a predator's diet by field observations, feeding studies are based on the examination of stomach contents that have not been fully digested. Usually, the identification of prey species, as well as the estimation of their length and weight, has been based on the analysis of otoliths. The otolith is a calcified structure that is differentially digested in the stomach of predators, completely dissolved (North et al. 1984; Jobling and Breiby 1986) or significantly eroded modifying their morphology and making measurements and taxonomic identification more complex (Johnstone et al. 1990). Thereby, the presence of certain species could be underestimated or ignored, leading to biased estimates of the original prey sizes and the amount of prey consumed (Jobling and Breiby 1986). Diagnostic bones concerning the body length allow estimating both the ingested biomass as the prey age class in the study of the diet of piscivorous predators (Gosztonyi et al. 2007). Nowadays, skull and shoulder girdle bones are a complement of the use of otoliths in diet studies because of its resistance to digestion (Hansel et al. 1988; Scharf et al. 1997, 1998; Gosztonyi et al. 2007; González Zeballos et al. 2010; Perez Comesaña et al. 2013, 2014).

This paper presents the linear regression and predictive total length equations for A. patachonicus based of the length of the cranial bones, scapular bones, otoliths and specific body meas- urements. These equations constitute a complementary tool to optimize the quantitative studies of the diet of marine piscivorous predators.

\section{MATERIALS AND METHODS}

Two hundred specimens of A. patachonicus captured by commercial bottom trawl vessels operating at Puerto Quequén, Buenos Aires Province, Argentina (fishing area: $38^{\circ} 40^{\prime} \mathrm{S}-39^{\circ}$ $\left.50^{\prime} \mathrm{S}, 57^{\circ} 68^{\prime}-60^{\circ} 08^{\prime} \mathrm{W}\right)$ during 2013 , were analysed. Total length, predorsal length, preanal length and head length in centimetres $( \pm 1 \mathrm{~mm}$ ) were registered (Figure 1) and immediately frozen. Diagnostic bones were selected according to Gosztonyi and Kuba (1996). Fish were placed in boiling water for a period no longer than $2 \mathrm{~min}$, depending on the size of the specimen, to remove bones. Once separated from the soft tissues, bones were measured using a calliper $( \pm 0.05$ $\mathrm{mm}$ ) (Figure 2). Least square regression equations were generated using INFOSTAT/L (Di Rienzo et al. 2010) to predict original total length of $A$. patachonicus based on the predorsal, preanal and head lengths. In addition, skull bones measurements such as hyoid bar length, cleithrum length, dentary length, maxilla length, premaxilla length, opercle length, preopercle length, vomer length, hyomandibula length, parasphenoids length and otolith length have been used (Figure 2). Total lengths were regressed on measurements of the remaining bones.

\section{RESULTS}

Total length of Argentine seabass ranged between 207 and $584 \mathrm{~mm}$. Regressions relating body measurements to total length were highly significant $(\mathrm{p}<0.0001)$. The coefficient of determination $\left(r^{2}\right)$ related to body measurements took 


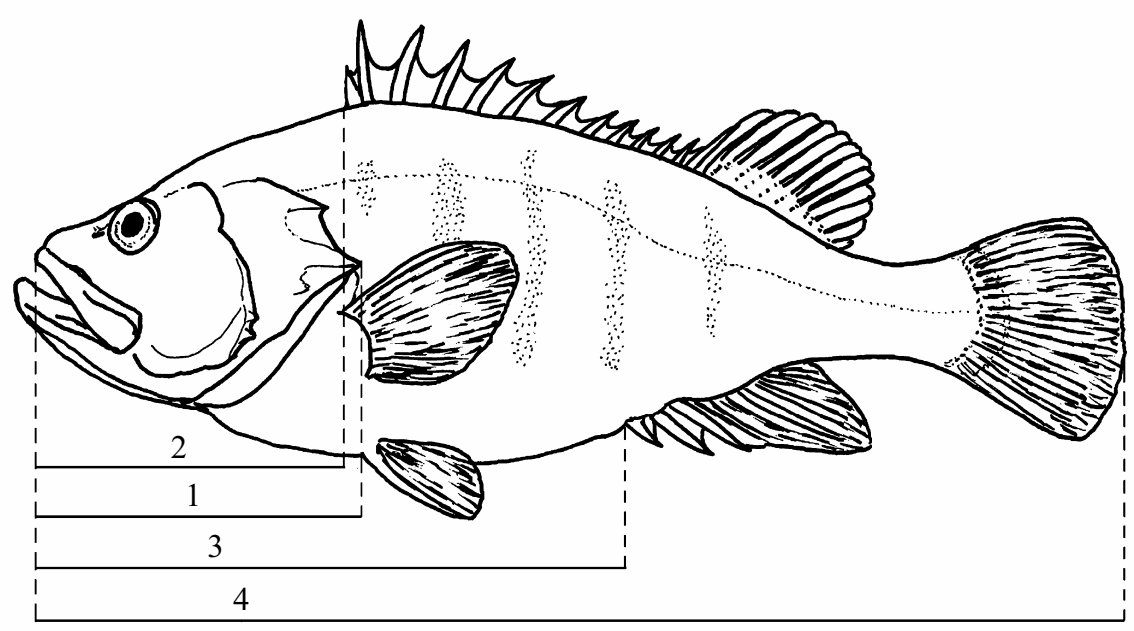

Figure 1. Body length measurements of Acanthistius patachonicus. 1: length of the head, 2: predorsal length, 3: preanal length, 4: total length.

values between 0.88 and 0.96 , being the preanal length the one that showed a better fit (Table 1). Also, values of the coefficient of determination for the lengths of diagnostic bones varied between 0.90 and 0.96 . The best fit was obtained with the preopercle (measure 2, Figure 2) $\left(r^{2}=\right.$ 0.96), slightly higher than those obtained with the opercle, hyoid bar, dentary (measure 1, Figure 2), all of them with $r^{2}=0.95$, and the cleithrum $\left(r^{2}=\right.$ $0.94)$, as well as the otolith length also showed a good fit $\left(r^{2}=0.91\right)$ (Table 1).

All measurements, whether from diagnostic bones or from body lengths or otoliths, showed significant relationship with total length. Regressions obtained from diagnostic bones, especially preopercle (measure 2), dentary (measure 1), opercle, hyoid bar and cleithrum appear to be reliable predictors of the length of $A$. patachonicus.

\section{DISCUSSION}

It is well known that the external morphology of a prey fish can be distorted by the effect of the predator's digestive process, which can lead to biased measurements. If prey was consumed recently, external morphological measurements can be estimated in an accurate way, becoming an appropriate alternative to that of the diagnostic bones, as is the case of the preanal length in the present work. However, back-calculation of the original dimensions of a fish from measurements of diagnostic bones is not as susceptible to error as that taken from external body measurements (Perez Comesaña et al. 2013).

It must also be recognized that reconstruction of the original size of fish prey from diagnostic bones has some limitations. The effect of preservatives on bone size should be taken into consideration if stomach contents are stored in a chemical stabilizer (Hansel et al. 1988; Scharf et al. 1997). Another potential problem is the use of boiling water to facilitate the separation of soft tissue bones. It can cause deformation and contraction of bones if an excessive time elapses between boiling and taking of measurements. These drawbacks were avoided in the present work since individuals were frozen, then thawed and boiled at controlled time intervals and subsequently measured after extraction and separation of bones.

In recent studies of the early development of $A$. patachonicus, preopercle complex has been pointed out as the most important characteristic 

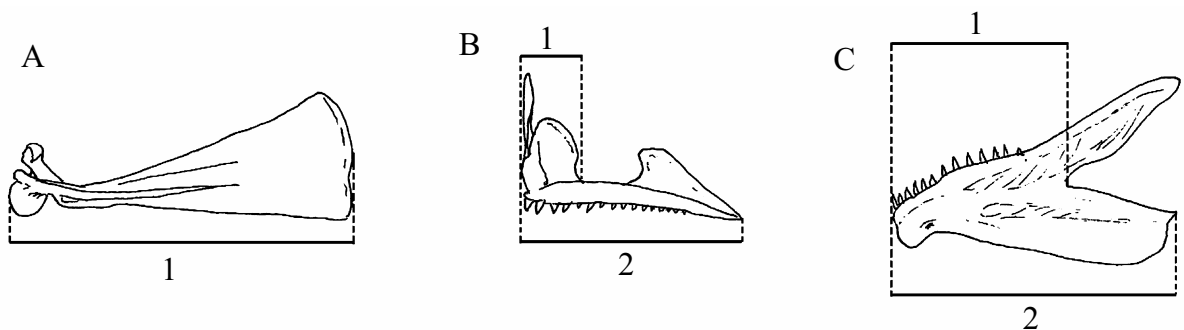

$\mathrm{D}$

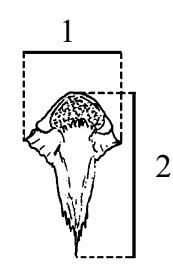

E

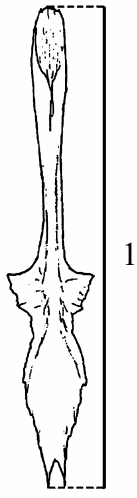

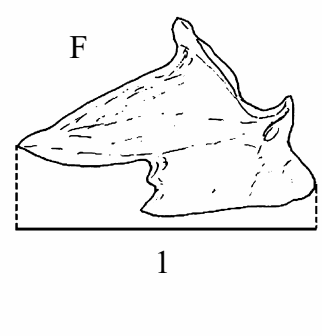
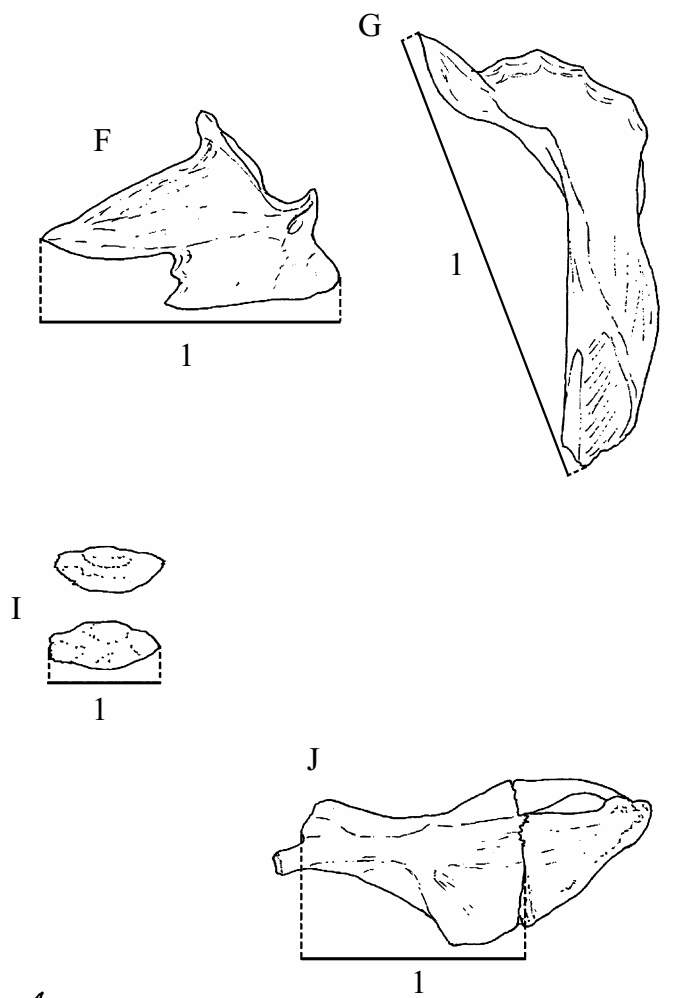

$\mathrm{H}$

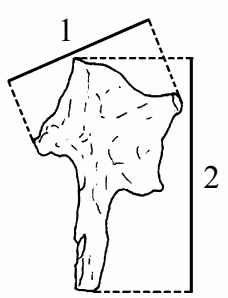

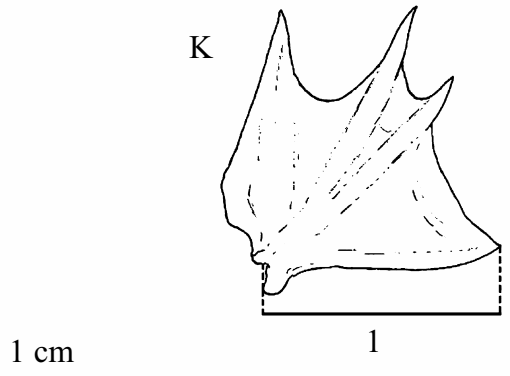

$1 \mathrm{~cm}$

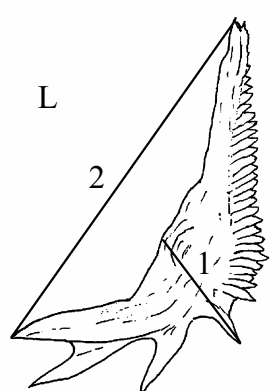

Figure 2. Bones and otolith measurements. A: maxilla, B: premaxilla, C: dentary, D: vomer, E: parasphenoids, F: angular, G: cleithrum, H: hyomandibula, I: otoliths, J: hyoid bar, K: opercle, L: preopercle. Numbers (1) and (2): registered measurements. 
Table 1. Estimated parameters of predictive regression equations of data versus total length Acanthistius patachonicus $(\mathrm{y}=\mathrm{a}+$ bx). x: variable in $\mathrm{mm}$, y: total length in $\mathrm{mm}, \mathrm{n}$ : sample size, $r^{2}$ : coefficient of determination, SE: standard error, CI: confidence interval. Numbers (1) and (2): measurements illustrated in Figure 2.

\begin{tabular}{lcccccc}
\hline Variables (mm) & & $\mathrm{n}$ & $r^{2}$ & $\mathrm{a} \pm \mathrm{SE}(\mathrm{CI} 95 \%)$ & $\mathrm{b} \pm \mathrm{SE}(\mathrm{CI} 95 \%)$ \\
\hline a. Maxilla & $(1)$ & 200 & 0.93 & $-6.03 \pm 6.71$ & $(-19.26-7.20)$ & $8.18 \pm 0.15(7.87-8.48)$ \\
b. Premaxilla & $(1)$ & 193 & 0.92 & $-12.04 \pm 7.80$ & $(-27.42--3.34)$ & $49.84 \pm 1.08(47.71-51.97)$ \\
& $(2)$ & 199 & 0.93 & $-10.19 \pm 6.80$ & $(-23.61-3.23)$ & $11.98 \pm 0.23(11.53-12.43)$ \\
c. Dentary & $(1)$ & 197 & 0.95 & $-8.46 \pm 5.93$ & $(-20.15-3.23)$ & $16.78 \pm 0.28(16.23-17.33)$ \\
& $(2)$ & 196 & 0.90 & $26.81 \pm 7.50$ & $(12.02-41.60)$ & $16.78 \pm 0.28(16.23-17.33)$ \\
d. Vomer & $(1)$ & 193 & 0.93 & $11.05 \pm 6.96$ & $(-2.68-24.77)$ & $36.82 \pm 0.76(35.33-38.42)$ \\
& $(2)$ & 191 & 0.91 & $-9.28 \pm 8.27$ & $(-25.59-7.03)$ & $15.48 \pm 0.36(14.78-16.19)$ \\
e. Parasphenoid & $(1)$ & 191 & 0.92 & $-30.00 \pm 8.22$ & $(-46.22--13.79)$ & $6.21 \pm 0.14(5.94-6.48)$ \\
f. Angular & $(1)$ & 197 & 0.91 & $-1.10 \pm 7.82$ & $(-16.53-14.33)$ & $9.34 \pm 0.21(8.93-9.75)$ \\
g. Cleithrum & $(1)$ & 180 & 0.94 & $-7.82 \pm 7.00$ & $(-21.63-5.99)$ & $5.18 \pm 0.10(4.98-5.38)$ \\
h. Hyomandibula & $(1)$ & 197 & 0.93 & $0.75 \pm 6.95$ & $(-12.97-14.46)$ & $16.62 \pm 0.33(15.97-17.28)$ \\
& $(2)$ & 187 & 0.93 & $-6.12 \pm 6.77$ & $(-19.47-7.24)$ & $12.10 \pm 0.23(11.64-12.55)$ \\
i. Otolith & $(1)$ & 197 & 0.91 & $-114.94 \pm 10.58(-135.82--94.07)$ & $31.30 \pm 0.72(29.89-32.72)$ \\
j. Hyoid bar & $(1)$ & 196 & 0.95 & $-19.32 \pm 6.04$ & $(-31.24--7.40)$ & $12.98 \pm 0.21(12.56-13.04)$ \\
k. Opercle & $(1)$ & 198 & 0.95 & $12.77 \pm 5.71$ & $(1.50-24.04)$ & $11.07 \pm 0.19(10.70-11.44)$ \\
1. Preopercle & $(1)$ & 198 & 0.90 & $-17.44 \pm 8.81$ & $(-34.82--0.06)$ & $19.75 \pm 0.48(18.81-20.69)$ \\
& $(2)$ & 198 & 0.96 & $-17.63 \pm 5.01$ & $(-27.51--7.75)$ & $7.56 \pm 0.10(7.35-7.76)$ \\
Head length & & 185 & 0.89 & $11.55 \pm 8.60$ & $(-5.42-28.52)$ & $2.96 \pm 0.08(2.81-3.12)$ \\
Predorsal length & & 183 & 0.88 & $53.66 \pm 8.13$ & $(37.61-69.71)$ & $2.95 \pm 0.08(2.79-3.11)$ \\
Preanal length & & 185 & 0.96 & $24.58 \pm 4.84$ & $(15.03-34.13)$ & $1.65 \pm 0.02(1.60-1.70)$ \\
\hline & & & & & &
\end{tabular}

that allowed the reconstruction of the development from larva to adult stage (Villanueva Gomila et al. 2015). Our results showed that two bones from the preopercle complex (preopercle and opercle) are also important as predictors of total length of $A$. patachonicus. Likewise, our results showed as well that dentary, hyoid and cleithrum bar bones, aside from the distance to the anterior insertion of the anal fin, are also good predictors of total length of $A$. patachonicus.

We have found that all measurements of the cranial bones of $A$. patachonicus showed a significant relationship with total length and that regressions obtained from diagnostic bones were reliable predictors of length. Thereby, regression equations calculated from cranial bones and external body measurements presented in this work increased the quali-quantitative potential of the information obtained from the analysis of stomach contents of piscivorous predators of the Southwestern Atlantic Ocean.

\section{ACKNOWLEDGEMENTS}

To Gustavo Carrizo for the drawings of the figures. Juan and Roque Bruno from the Santa Cecilia fish market. To José Ricci for share their facilities. To the reviewers for the constructive comments on earlier draft of the manuscript. INIDEP contribution no 2163. 


\section{REFERENCES}

Alonso SH, Switzer PV, Mangel M. 2003. An ecosystem based approach to management: using individual behaviour to predict the indirect effects of Antarctic krill fisheries on penguin foraging. J Appl Ecol. 40: 692-702.

Cherel Y, Weimersirirch H, Trouvé C. 2000. Food and feeding ecology of the neritic-slope forager black-browed albatros and its relationships with commercial fisheries in Kerguelen waters. Mar Ecol Prog Ser. 207: 183-199.

Cousseau MB, Perrotta RG. 1998. Peces marinos de Argentina. Biología, distribución, pesca. Mar del Plata: Instituto Nacional de Investigación y Desarrollo Pesquero (INIDEP). $167 \mathrm{p}$.

Di Rienzo JA, Casanoves F, Balzarini MG, González L, Tablada M, Robledo CW. 2010. InfoStat versión 2010. Grupo InfoStat, FCA, Universidad Nacional de Córdoba, Argentina.

GonzÁlez Zeballos D, Kuba L, Gosztonyi AE. 2010. Estimación de la longitud utilizando relaciones morfométricas de huesos del cráneo, cintura escapular, otolitos y medidas específicas del cuerpo en Merluccius hubbsi en aguas patagónicas. Rev Biol Mar Oceanogr. 45: 341-345.

Gosztonyi AE, KubA L. 1996. Atlas de huesos craneales y de la cintura escapular de peces costeros patagónicos. Informe Técnico $\mathrm{N}^{\mathrm{o}} 4$. Fundación Patagonia Natural, Puerto Madryn, Argentina. 29 p.

Gosztonyi AE, Kuba L, Manzur LE. 2007. Estimation of body size using morphometric relationships of head bones, pectoral fin bones and bony precaudal distance in Raneya brasiliensis (Kaup, 1856) (Pisces, Ophidiiformes, Ophidiidae) in Patagonian waters. Rev Biol Mar Oceanogr. 42: 1-5.

Hansel HC, Duke SD, Lofy PT, Gray GA.
1988. Use of diagnostic bones to identify and estimate original lengths of ingested prey fishes. Trans Am Fish Soc. 117: 55-62.

Jobling M, BreIBY A. 1986. The use and abuse of fish otoliths in studies of feeding habits of marine piscivores. Sarsia. 71: 265-274.

Johnstone IG, Harris M P, Wanless S, Graves JA.1990. The usefulness of pellets for assessing the diet of adult Shags Phalacrocorax aristotelis. Bird Study. 37 (1): 5-11.

Koen Alonso M, Crespo EA, Pedraza SN, García NA, Coscarella MA. 2000. Food habits of the South American sea lion Otaria flavescens, off Patagonia, Argentina. Fish Bull. 98: 250-263.

LUCIFORA LO. 2003. Ecología y conservación de los grandes tiburones costeros de Bahía Anegada, Provincia de Buenos Aires Argentina [tesis doctoral]. Mar del Plata: Facultad de Ciencias Exactas y Naturales, Universidad Nacional de Mar del Plata. 405 p.

LuCifora LO, García VB, MENNI RC, EscalanTE AH. 2006. Food habits, selectivity, and foraging modes of the school shark Galeorhinus galeus. Mar Ecol Prog Ser. 315: 259-270.

Lyons J, Magnuson JJ. 1987. Effects of walleys predation on the population dynamics of small littoral-zone fishes in a northern Wisconsin lake. Trans Am Fish Soc. 116: 29-39.

North AW, Burchett MS, Gilbert CJ, White MG. 1984. Identification of fish from the southern ocean by means of otoliths. BAS Bulletin. 62: 83-94.

Pauly D, Christensen V, Dalsgaard J, Froese R, TORres F. 1998a. Fishing down marine food webs. Science. 279: 860-863.

Pauly D, Christensen V, Guénette S, Pitcher TJ, Sumaila UR, Walters CJ, Watson R, ZELLER D. 2002. Towards sustainability in world fisheries. Nature. 418: 689-684.

Pauly D, Palomares ML, Froese R, Sa AP, Vakily M, Preikshot D, Wallace S. 2001. Fishing down Canadian aquatic food webs. Can J Fish Aquat Sci. 58: 51-62. 
Pauly D, Trites AW, Capuli E, Christensen V. 1998b. Diet composition and trophic levels of marine mammals. ICES J Mar Sci. 55: 467481.

Perez Comesaña Je, Bechthold C, Arias K, Carrizo GR, Riestra C. 2014. Estimación de la longitud de la pescadilla de red (Cynoscion guatucupa) (Actinopterygii: Sciaenidae) utilizando relaciones morfométricas de huesos del cráneo y de la cintura escapular, otolitos y medidas específicas del cuerpo. Rev Mus Argentino Cienc Nat ns. 16 (1): 89-93.

Perez Comesaña, Je, Clavin P, Arias K, RiesTRA C. 2013. Total length estimation of the Brazilian flathead Percophis brasiliensis, using morphometric relationships of skull, pectoral girdle bones, otoliths and specific body measures, in Argentine waters. J Appl Ichthyol. 30: 377-380.

Scharf FS, Buckel JA, JuAnes F, Conover DO. 1997. Estimating piscine prey size from par- tial remains: testing for shifts in foraging mode by juvenile bluefish. Environ Biol Fish. 49: 377-388.

Scharf FS, YeTter RM, Summers AP, JuANes F. 1998. Enhancing diet analyses of piscivorous fishes in the Northwest Atlantic through identification and reconstruction of original prey sizes from ingested remains. Fish Bull. 96: 575-588.

Tonn WM, Paszkowski CA, Holopainen IJ. 1992. Piscivory and recruitment; mechanisms structuring prey populations in small lakes. Ecology. 73: 951-958.

Villanueva Gomila L, Ehrlich MD, Venerus LA. 2015. Early life history of the Argentine sea bass (Acanthistius patachonicus) (Pisces: Serranidae). Fish Bull. 113: 456-467.

Received: 9 January 2020

Accepted: 1 May 2020 
